\title{
PENGARUH KERJASAMA TERHADAP KINERJA PEGAWAI PADA BIRO HUMAS DAN PROTOKOL SEKRETARIAT DAERAH PROVINSI LAMPUNG
}

\author{
Ika Nensi Sinar Maharatu A ${ }^{(1)}$, Fahrizi ${ }^{(2)}$, Maria Elina ${ }^{(3)}$ \\ Fakultas Ekonomi Universitas Sang Bumi Ruwa Jurai \\ ikanensi.maharatu@gmail.com,fahrizi@fe.saburai.ac.id,maria.elina@fe.saburai.ac.id
}

\begin{abstract}
Abstrak. Keberhasilan pelaksanaan tugas, fungsi dan kewenangan Biro Humas dan Protokol Sekretariat Daerah Provinsi Lampung merupakan bagian yang tidak terpisahkan dari keseluruhan proses pelaksanaan pembangunan di Provinsi Lampung. Masalah dalam penelitian ini, yaitu kegiatan penyebarluasan informasi ke publik yang telah dilaksanakan oleh Biro Humas dan Protokol Sekretariat Daerah Provinsi Lampung setiap tahunnya tidak pernah tercapai. Pencapaian tertinggi terjadi pada tahun 2012 sebesar 80,77\% dan pencapaian terendah terjadi pada tahun 2016 yaitu 70,59\%. Tingkat pencapaian target kegiatan penelitian dan pengembangan di bidang evaluasi berfluktuasi cenderung menurun setiap tahunnya, dengan rata-rata pencapaian selama 5 (lima) tahun sebesar 76,36\%. Tujuan dari penelitian ini adalah untuk mengetahui dan menganalisis pengaruh kerjasama terhadap kinerja pegawai pada Biro Humas dan Protokol Sekretariat Daerah Provinsi Lampung. Pengumpulan data penelitian menggunakan teknik sampel penelitian dari 52 responden. Metode penelitian yang digunakan adalah analisis kualitatif dan analisis kuantitatif yaitu regresi linier sederhana. Berdasarkan hasil analisis diperoleh persamaan bahwa $Y=16,716+0,563 X$. Kerjasama memiliki pengaruh besar yaitu sebesar 40,7 \% terhadap kinerja Pegawai di Biro Humas dan Protokol Sekretariat Daerah Provinsi Lampung.
\end{abstract}

Kata kunci: Kerjasama, Kinerja, Pegawai, Regresi.

\section{PENDAHULUAN}

Keberhasilan pelaksanaan tugas, fungsi dan kewenangan Biro Humas dan Protokol Sekretariat Daerah Provinsi Lampung merupakan bagian yang tidak terpisahkan dari keseluruhan proses pelaksanaan pembangunan di Provinsi Lampung pada khususnya serta pembangunan Nasional pada umumnya yang diarahkan untuk mewujudkan cita-cita luhur bangsa Indonesia untuk menuju masyarakat yang adil, makmur, sejahtera, mandiri dan bermartabat sesuai dengan peraturan perundang-undangan yang berlaku.

Sesuai Peraturan Daerah Provinsi Lampung Nomor 11 Tahun 2014 tentang Pembentukan Organisasi, dan Tata Kerja Dinas Daerah Provinsi Lampung merupakan dasar hukum perubahan humas Dinas Komunikasi dan Informatika menjadi Biro Humas dan Protokol Provinsi
Lampung pada awal tahun yakni bulan Januari 2015. Biro Humas dan Protokol Provinsi Lampung beralamatkan di Jalan WR Monginsidi No. 69 Telukbetung.

Mencermati perubahan Nomenklutar Dinas sebagaimana tersebut di atas merupakan salah satu bentuk kebijaksanaan Pemerintah Daerah Provinsi Lampung dalam rangka efisiensi dan menghindari tumpang tindih tugas, dan fungsi sejenis. Demikian jelas bahwa tugas dan fungsi Biro Humas dan Protokol Provinsi Lampung semakin lebih luas, bahkan memungkinkan untuk melakukan operasional pelayanan informasi secara aktif.

Berdasarkan Perda Provinsi Lampung Nomor 11 Tahun 2014, Biro Humas dan Protokol berkedudukan sebagai unsur auxiliary staff yang memberi dukungan pelayanan internal kepada instansi di jajaran Pemerintah Provinsi dan pelayanan 
langsung kepada masyarakat, khususnya media massa. Sebagai auxiliary staff, Biro Humas mempunyai tugas pokok, yakni: "Menyiapkan perumusan kebijakan, mengkoordinasikan pelaksanaan tugas dan fungsi, pemantapan dan evaluasi program kegiatan dan penyelenggaraan pembinaan teknis, administrasi dan sumberdaya di bidang hubungan masyarakat dan tugastugas keprotokolan". Untuk melaksanakan tugas tersebut, Biro Humas dan Protokol mempunyai fungsi:

1. Juru Bicara Gubernur dan Pemerintah Provinsi.

2. Pelaksanaan penyiapan perumusan kebijakan di bidang hubungan masyarakat dan protokol.

3. Pelaksanaan koordinasi dan penyusunan program kegiatan serta petunjuk teknis pelaksanaan di bidang pengumpulan dan penyaringan informasi, media, dokumensi dan protokol.

4. Pelaksanaan monitoring dan evaluasi penyelenggaraan pemerintah dan pembangunan di bidang pengumpulan dan penyaringan informasi, media dan dokumentasi dan protokol.

5. Pelaksana pembinaan administrasi pemerintahan dan pembangunan serta sumberdaya aparatur di bidang hubungan masyarakat dan protokol.

6. Pelaksanaan tugas-tugas lain yang diberikan Asisten.

Pelaksanaan tugas pokok dan fungsi sebagaimana dimaksud di atas, maka diperlukan adanya daya dukung dari Pegawai Negeri Sipil. Pegawai sebagai sumber daya manusia mempunyai peranan yang besar dalam mengemban tugas yang diberikan oleh organisasi, khususnya menyiapkan perumusan kebijakan, mengkoordinasikan pelaksanaan tugas dan fungsi, pemantapan dan evaluasi program kegiatan dan penyelenggaraan pembinaan teknis, administrasi dan sumberdaya di bidang hubungan masyarakat dan tugas- tugas keprotokolan. Untuk meningkatkan kinerja tersebut salah satunya diperlukan adanya faktor pendukung yaitu kerjasama.

Kondisi kerjasama baik intern maupun ekstern yang terjadi di Biro Humas dan Protokol Sekretariat Daerah Provinsi Lampung apabila tidak diperbaiki akan menurunkan kinerja, hal ini sesuai dengan pendapat Richard (2005:81), bahwa kedisiplinan dan kerjasama sebagai bentuk lingkungan kerja nonfisik atau psikologis dalam suatu organisasi akan mampu memberikan dampak terhadap pencapaian kinerja pegawai. Hal ini menunjukkan jika dengan kerjasama yang baik maka akan meningkatkan kinerja pegawai, begitu juga sebaliknya, dengan kerjasama yang kurang baik akan menurunkan kinerja pegawai.

Berdasarkan hasil observasi yang dilakukan, terlihat ada sebagian pegawai yang belum menyadari bahwa dirinya dalam menjalankan tugasnya harus dengan sungguh-sungguh, ikhlas dan tidak asalasalan, sehingga berdampak pada terhambatnya proses penyelesaian pekerjaan yang menjadi tanggung jawabnya. Di sisi lain, pegawai kurang bertanggung jawab terhadap tugasnya, hal ini dapat dilihat masih adanya para pegawai yang meninggalkan kantor pada jam kerja dengan alasan yang tidak dapat dipertanggungjawabkan, ada oknum pegawai yang tidak ikut apel, cepat pulang sebelum waktunya tanpa alasan yang jelas, pegawai yang mangkir kerja dengan alasan kesehatan atau keperluan keluarga. Berbagai fenomena tersebut, secara tidak langsung berdampak pencapaian target kerja yang telah ditetapkan.

Berdasarkan fenomena yang telah diuraikan sebelumnya, terlihat bahwa kerjasama yang tercipta antara sesama pegawai masih kurang harmonis, sehingga hal ini berdampak pada pencapaian kinerja pegawai dilihat dari kegiatan penyebarluasan informasi yang telah dilaksanakan oleh Biro Humas dan Protokol 
Sekretariat Daerah Provinsi Lampung setiap tahunnya tidak pernah tercapai. Penulis tertarik untuk meneliti lebih lanjut dengan Judul: "Pengaruh Kerjasama Terhadap Kinerja Pegawai Pada Biro Humas dan Protokol Sekretariat Daerah Provinsi Lampung”.

\section{KAJIAN TEORI}

\section{Pengertian Kerjasama}

Organisasi pada lembaga pemerintahan memiliki bermacam-macam kegiatan dimana kegiatan satu dengan yang lainnya saling berhubungan serta merupakan satu kesatuan dalam mencapai tujuan. Keterkaitan itu sering timbul saling ketergantungan sehingga memerlukan suatu kerjasama agar tujuan dapat tercapai. Kerjasama itu timbul disebabkan oleh keterbatasan yang dimiliki oleh setiap individu dalam melakukan tugas-tugas dan tanggung jawabnya.

Barnard (2001) memberikan pengertian kerjasama, bahwa kerjasama membenarkannya sendiri, lalu sebagai alat untuk mengatasi keterbatasan yang membatasi apa yang dapat dilakukan individu. Oleh karena itu, kerjasama merupakan alat untuk mengatasi keterbatasan individu. Chung dan Megginson (2008) menyebutkan kerjasama merupakan perbuatan beberapa orang secara bersama-sama yang memberikan hasil, sedangkan hasil tersebut tidak akan terjadi apabila hanya dilakukan secara perorangan. Pareek (2003) memberikan pengertian bahwa kerjasama dapat didefinisikan dalam kaitan dengan seseorang yang bekerja dengan orang lain untuk mencapai suatu tujuan yang dianggap dapat dibagi.

Menurut Abdulsyani (2004), kerjasama merupakan salah satu bentuk interaksi sosial, dimana di dalamnya terdapat aktivitas tertentu untuk mencapai tujuan bersama dengan saling membantu dan saling memahami aktivitas masing-masing. Atau dengan kata lain, kerjasama berarti bekerja secara bersama-sama untuk mencapai tujuan bersama. Ia adalah satu proses sosial yang paling dasar. Biasanya, kerjasama melibatkan pembagian tugas, dimana setiap orang mengerjakan setiap pekerjaan yang merupakan tanggung jawab demi tercapainya tujuan bersama.

Pengertian kerjasama dalam istilah administrasi, sebagaimana dijelaskan oleh Nawawi (2005) kerjasama adalah usaha untuk mencapai tujuan bersama yang telah ditetapkan melalui pembagian tugas/pekerjaan, tidak sebagai pengkotakan kerja akan tetapi sebagai satu kesatuan kerja, yang semuanya terarah pada pencapaian tujuan.

Kerjasama adalah sebuah sistem pekerjaan yang kerjakan oleh dua orang atau lebih untuk mendapatkan tujuan yang direncanakan bersama. Kerjasama dalam tim kerja menjadi sebuah kebutuhan dalam mewujudkan keberhasilan kinerja dan prestasi kerja. Kerjasama dalam tim kerja akan menjadi suatu daya dorong yang memiliki energi dan sinergisitas bagi individu-individu yang tergabung dalam kerja tim. Komunikasi akan berjalan baik dengan dilandasi kesadaran tanggung jawab tiap anggota.

\section{Jenis-Jenis Kerjasama}

Terdapat tiga jenis kerjasama yang didasarkan perbedaan dalam organisasi grup atau di dalam sikap grup, yaitu :

a. Kerjasama primer

Di sini grup dan individu sungguhsungguh dilebur menjadi satu. Grup berisi seluruh kehidupan daripada individu dan masing-masing saling mengejar untuk masing-masing pekerjaan, demi kepentingan seluruh anggota dalam grup ini. Contohnya adalah kehidupan rutin sehari-hari dalam 
biara, kehidupan keluarga pada masyarakat primitif dan lain-lainnya (Ahmadi, 2004).

b. Kerjasama sekunder

Apabila kerjasama primer karakteristik ada pada masyarakat primitif, maka kerjasama sekunder adalah khas pada masyarakat modern. Kerjasama sekunder ini sangat diformalisir dan spesialisir dan masing-masing individu hanya membaktikan sebagian dari pada hidupnya untuk grup yang dipersatukan dengan itu. Sikap orang-orang disini lebih individualitis dan mengadakan perhitungan-perhitungan. Contohnya adalah kerjasama dalam kantor-kantor dagang, pabrik-pabrik, pemerintahan dan sebagainya (Narwoko, 2004).

c. Kerjasama tersier

Dalam hal ini yang menjadi dasar kerjasama adalah konflik yang laten. Sikap-sikap dari pihak-pihak yang kerjasama adalah murni oportunis. Organisasi mereka sangat longgar dan gampang pecah, bila alat bersama itu tidak lagi membantu masing-masing pihak dalam mencapai tujuannya. Contohnya adalah hubungan buruh dengan pimpinan (Ahmadi, 2004).

\section{Pengertian Kinerja Pegawai}

Mathis dan Jackson (2002) berpendapat bahwa kinerja pegawai adalah yang mempengaruhi seberapa banyak mereka memberi kontribusi kepada organisasi, yang antara lain termasuk: kuantitas, kualitas, jangka waktu, kehadiran di tempat kerja dan sikap kooperatif. Ditambahkan oleh Foster dan Seeker (2001), bahwa kinerja seorang pegawai dipengaruhi oleh pengetahuan, keterampilan, motivasi dan kepercayaan diri.
Menurut Suprihanto (2004), kinerja adalah kemampuan kerja seorang pegawai yang dapat dibuktikan dari hasil kerja sehari-hari yang dapat memberikan nilai lebih bagi kemajuan unit kerja atau organisasinya. Setiap pegawai diharapkan memiliki kinerja (prestasi kerja) yang memuaskan, sehingga sinergi dari prestasiprestasi pegawai akan dapat meningkatkan dan mengembangkan eksistensi organisasi di tengah-tengah masyarakat. Adapun manajemen kinerja pada dasarnya berkaitan dengan usaha, kegiatan atau program yang diprakarsai dan dilaksanakan oleh pimpinan organisasi untuk merencanakan, mengarahkan dan mengendalikan prestasi karyawan (Ruky, 2004).

Dengan demikian, dapat dikatakan bahwa manajemen kinerja merupakan upaya yang dilakukan oleh pimpinan organisasi untuk membina paradigma baru atau mengembangkan kinerja pegawai. Sebagai bagian dari manajemen, maka dengan pembinaan kinerja pada dasarnya merupakan upaya yang dilakukan oleh pimpinan pegawai untuk membina/mengembangkan kinerja pegawainya. Karena program ini mencantumkan kata manajemen, seluruh kegiatan yang dilakukan dalam sebuah proses manajemen harus terjadi dimulai dengan menetapkan tujuan dan sasaran yang ingin dicapai, kemudian tahap pembuatan rencana, pengorganisasian, penggerakan/pengarahan dan akhirnya evaluasi atas hasilnya. Secara teknis, program ini memang harus dimulai dengan menetapkan tujuan dan sasaran yaitu kinerja dalam bentuk apa dan yang seperti bagaimana yang ingin dicapai.

Menurut beberapa literatur Manajemen Sumber Daya Manusia diketahui bahwa penilaian kinerja dengan berbagai variasi sebutan, seperti penilaian kinerja, penilaian karyawan penilaian karyawan, penilaian prestasi kerja, penilaian efisiensi atau penilaian layanan (Mangkunegara, 2004), 
pada prinsipnya, merupakan cara pengukuran kontribusi-kontribusi dari individu dalam instansi yang dilakukan terhadap organisasi. Nilai penting dari penilaian kinerja adalah menyangkut penentuan tingkat kontribusi individu atau kinerja yang diekspresikan dalam penyelesaian tugas-tugas yang menjadi tanggung jawabnya (Sulistyani, 2003). Hal ini diperkuat oleh pendapat Chung dan Meggison (2008) yang mengartikan penilaian kinerja sebagai sebuah cara untuk mengukur kontribusi individu terhadap organisasinya.

Kinerja merupakan hasil dari kerja yang dilakukan dan bagaimana proses mencapai hasil tersebut. Menurut Sentono (2003), kinerja adalah hasil kerja yang dapat dicapai oleh seseorang atau sekelompok orang dalam organisasi sesuai dengan wewenang dan tanggung jawab dalam rangka mencapai tujuan organisasi secara legal dan tidak melanggar hukum, sejauhmana keberhasilan seseorang dalam melakukan tugas pekerjaannya dinamakan tingkat kinerja dan untuk mengukur kinerja pegawai maka masalah pokok adalah menetapkan persyaratan kerja dan kriterianya.

\section{Indikator Kinerja Pegawai}

Definisi lain dijelaskan bahwa kinerja pegawai adalah suatu pekerjaan yang dicapai seorang pegawai dalam melaksanakan tugas dan pekerjaannya yang dibebankan kepadanya. Dijelaskan pula oleh Sulistyani (2003) bahwa indikator dari kinerja pegawai adalah sebagai berikut :

1. Ketaatan ialah kesanggupan seorang PNS untuk menaati segala peraturan perundangan dan kedinasan yang berlaku.

2. Prestasi kerja ialah hasil kerja yang dicapai seorang PNS dalam melaksanakan tugas yang diberikan kepadanya, yang dipengaruhi oleh kecakapan, pengalaman dan kesungguhan.

3. Kesetiaan/loyalitas, ialah kesanggupan untuk mentaati, melaksanakan dan mengamalkan sesuatu yang ditaati dengan penuh kesadaran dan tanggung jawab.

4. Tanggung jawab ialah kesanggupan seorang PNS dalam menyelesaikan pekerjaan yang diserahkan kepadanya dengan sebaik-baiknya dan tepat waktu, serta berani memikul resiko atas keputusan yang telah diambil.

5. Kejujuran ialah ketulusan hati seorang PNS dalam melaksanakan tugas dan kemampuan untuk tidak menyalahgunakan wewenang yang diberikan.

6. Kerjasama ialah kemampuan seorang PNS untuk bekerjasama dengan orang lain dalam menyelesaikan tugas yang diberikan sehingga mencapai daya guna dan hasil guna secara optimal.

7. Prakarsa ialah kemampuan seorang PNS untuk mengambil keputusan atau melaksanakan tindakan yang diperlukan dalam pelaksanaan tugas.

\section{METODE PENELITIAN}

\section{Objek Penelitian}

Tempat yang dijadikan sebagai obyek dalam penelitian ini adalah Biro Humas dan Protokol Sekretariat Daerah Provinsi Lampung. Biro Humas dan Protokol Sekretariat Daerah Provinsi Lampung beralamatkan di Jalan WR Monginsidi No. 69 Telukbetung.

\section{Metode dan Teknik Pengumpulan Data}

Dalam penelitian ini jenis data yang diperlakukan adalah :

a. Data Primer

Data primer merupakan data dasar yang akan diperoleh langsung tanpa 
perantara orang atau lembaga lain sebagai pihak ketiga. Data primer ini diperoleh dengan wawancara melalui responden dengan menggunakan daftar pertanyaan.

b. Data Sekunder

Data skunder merupakan data yang diperoleh melalui orang lain yang berhubungan dengan permasalahan yang dipecahkan. Data sekunder ini diperoleh melalui cara studi dokumenter yaitu mengumpulkan dan mempelajari brosurbrosur serta dokumen organisasi.

Langkah-langkah pengumpulan data yang penulis lakukan dengan mengadakan penelitian lapangan yaitu Penelitian yang dilakukan di Kantor Biro Humas dan Protokol Sekretariat Daerah Provinsi Lampung, adapun teknik yang digunakan dalam pengumpulan data adalah dengan :

1. Observasi, yaitu mengadakan survey atau pengamatan langsung kelokasi penelitian.

2. Interview atau wawancara, yaitu mengadakan tanya jawab langsung dengan pegawai pada Kantor Biro Humas dan Protokol Sekretariat Daerah Provinsi Lampung.

3. Dokumentasi, yaitu mengumpulkan dan mencatat dokumentasi yang relevan.

4. Quisioner, yaitu membuat pertanyaan yang berhubungan dengan variabel penelitian.

\section{Sampel dan Populasi}

Menurut Sugiyono (2010), populasi adalah wilayah generalisasi yang terdiri atas obyek/subyek yang mempunyai kualitas dan karakteristik tertentu yang ditetapkan oleh peneliti untuk dipelajari dan kemudian ditarik kesimpulannya. Dalam penelitian ini yang menjadi populasi adalah seluruh pegawai di Biro Humas dan Protokol Sekretariat Daerah Provinsi Lampung berjumlah 52 orang tidak termasuk Kepala Bagian dan peneliti.

Sugiyono (2010) mengemukakan bahwa sampel adalah bagian dari jumlah dan karakteristik yang dimiliki oleh populasi. Menurut Arikunto (2002) "Apabila objek penelitian kurang dari 100 lebih baik diambil semuanya sehingga penelitiannya merupakan penelitian populasi atau sensus. Selanjutnya jika jumlah objek lebih besar dari 100 maka dapat antara $10-15 \%$ atau $20-25 \%$ ".

Berdasarkan pendapat tersebut, maka dalam penelitian ini diambil seluruh anggota populasi yaitu 52 orang pegawai atau penelitian sensus.

\section{Metode Analisis Data}

Analisis kualitatif yaitu analisis yang menggambarkan secara rinci, dengan interpretasi terhadap data yang diperoleh dalam bentuk tabulasi melalui pendekatan teoritis. Analisis kualitatif ini dimaksudkan untuk mengetahui karakteristik responden dan karakteristik data variabel kerjasama dan kinerja pegawai yang meliputi distribusi frekuensi dan rata-rata skor pencapaian.

Analisis kuantitatif yang dilakukan berdasarkan data primer yang diperoleh dari penyebaran instrument (daftar pertanyaan) kepada sampel, dan untuk mengetahui pengaruh dari variabel bebas (independent variable) terhadap variabel terikat (dependent variable).

Persamaan Regresi Linear Sederhana menentukan persamaan regresi linear sederhana untuk X :

$$
Y=a+b X+e
$$

Keterangan:

$$
\begin{aligned}
\mathrm{Y} & =\text { Kinerja Pegawai } \\
\mathrm{a} & =\text { Konstanta } \\
\mathrm{b} & =\text { Koefisien regresi } \mathrm{X}
\end{aligned}
$$


$\mathrm{X}=$ Kerjasama

$\mathrm{e}=$ Faktor kesalahan

Untuk mengetahui besarnya pengaruh, penghitungan koefisien korelasi tersebut kemudian dilanjutkan dengan Rumus Koefisien Determinasi atau Koefisien Penentu (KP):

$$
K P=(r)^{2} x 100 \%
$$

Untuk menguji secara hipotesis secara parsial digunakan Uji t dengan rumus :

$$
t_{\text {hitung }}=\frac{r \sqrt{N-2}}{\sqrt{1-r^{2}}}
$$

Keterangan:

$$
\begin{array}{ll}
\mathrm{t}_{\text {hitung }} & =\text { Nilai } \mathrm{t} \\
\mathrm{r} & =\text { Koefisien Korelasi } \\
\mathrm{N} & =\text { Jumlah responden }
\end{array}
$$

Kriteria untuk Uji $\mathrm{t}$ adalah sebagai berikut :

a) Jika $t_{\text {hitung }}>t_{\text {tabel }}$ maka Ha diterima dan Ho ditolak.

b) Jika $t_{\text {hitung }} \leq \mathrm{t}_{\text {tabel }}$ maka Ha ditolak dan Ho diterima.

\section{HASIL DAN PEMBAHASAN}

\section{Uji Validitas dan Reliabilitas Instrumen}

Sebelum kuisioner disebarkan kepada seluruh responden dilakukan uji coba kuisioner dengan menyebarkan kuisioner kepada 30 (tiga puluh) orang, di luar sampel penelitian. Uji coba ini dilakukan untuk menguji tingkat validitas dan reliabilitas pernyataan-pernyataan yang diajukan dalam penelitian.

Uji validitas data dalam penelitian ini dinyatakan dengan nilai Corrected-Item Total Correlation. Kategori pengujian, apabila $\mathrm{r}_{\text {hitung }}>\mathrm{r}_{\text {tabel}}$, maka item soal tersebut dinyatakan valid, demikian pula sebaliknya. Berdasarkan hasil pengolahan data diperoleh hasil sebagaimana terlihat Tabel 1.

Berdasarkan Tabel 1. terlihat bahwa nilai Corrected-Item Total Correlation yang terendah yaitu 0,591 pada instrumen nomor 4 dan tertinggi yaitu 0,800 pada instrumen nomor 6. Dengan demikian disimpulkan bahwa instrumen yang

\begin{tabular}{|c|c|c|c|c|}
\hline Item Pernyataan & $\mathrm{r}_{\text {hitung }}$ & $\mathrm{r}_{\text {tabel }}$ & Kondisi & Simpulan \\
\hline Pernyataan_1 & 0,765 & 0,361 & $\begin{array}{c}\mathrm{r}_{\text {hitung }}> \\
\mathrm{r}_{\text {tabel }}\end{array}$ & Valid \\
\hline Pernyataan_2 & 0,743 & 0,361 & $\begin{array}{c}\mathrm{r}_{\text {hitung }}> \\
\mathrm{r}_{\text {tabel }}\end{array}$ & Valid \\
\hline Pernyataan_3 & 0,756 & 0,361 & $\begin{array}{c}\mathrm{r}_{\text {hitung }}> \\
\mathrm{r}_{\text {tabel }}\end{array}$ & Valid \\
\hline Pernyataan_4 & 0,591 & 0,361 & $\begin{array}{c}\mathrm{r}_{\text {hitung }}> \\
\mathrm{r}_{\text {tabel }}\end{array}$ & Valid \\
\hline Pernyataan_5 & 0,678 & 0,361 & $\begin{array}{c}\mathrm{r}_{\text {hitung }}> \\
\mathrm{r}_{\text {tabel }}\end{array}$ & Valid \\
\hline Pernyataan_6 & 0,800 & 0,361 & $\begin{array}{c}\mathrm{r}_{\text {hitung }}> \\
\mathrm{r}_{\text {tabel }}\end{array}$ & Valid \\
\hline Pernyataan_7 & 0,767 & 0,361 & $\begin{array}{c}\mathrm{r}_{\text {hitung }}> \\
\mathrm{r}_{\text {tabel }}\end{array}$ & Valid \\
\hline Pernyataan_8 & 0,682 & 0,361 & $\begin{array}{c}\mathrm{r}_{\text {hitung }}> \\
\mathrm{r}_{\text {tabel }}\end{array}$ & Valid \\
\hline Pernyataan_9 & 0,779 & 0,361 & $\begin{array}{c}\mathrm{r}_{\text {hitung }}> \\
\mathrm{r}_{\text {tabel }}\end{array}$ & Valid \\
\hline Pernyataan_10 & 0,644 & 0,361 & $\begin{array}{c}\mathrm{r}_{\text {hitung }}> \\
\mathrm{r}_{\text {tabel }}\end{array}$ & Valid \\
\hline
\end{tabular}
diujicobakan memiliki validitas (sesuai dengan yang akan diukur).

Tabel 1. Hasil Uji Validitas Instrumen Kerjasama $\left(\mathrm{X}_{1}\right)$

Berdasarkan Tabel 2. terlihat bahwa nilai Corrected-Item Total Correlation yang terendah yaitu 0,605 pada instrumen nomor 4 dan nilai Corrected-Item Total Correlation tertinggi yaitu 0,813 pada instrumen nomor 5. Dengan demikian disimpulkan bahwa instrumen yang 
diujicobakan memiliki validitas (sesuai dengan yang akan diukur).

Tabel 2. Hasil Uji Validitas Instrumen Kinerja Pegawai (Y)

\begin{tabular}{|c|c|c|c|c|c|}
\hline Item Pernyataan & $\mathrm{r}_{\text {hitung }}$ & $\mathrm{r}_{\text {tabel }}$ & Kondi & & Simpulan \\
\hline Pernyataan_1 & 0,748 & 0,361 & $\begin{array}{l}\mathrm{r}_{\text {hitung }} \\
\mathrm{r}_{\text {tabel }}\end{array}$ & $>$ & Valid \\
\hline Pernyataan_2 & 0,739 & 0,361 & $\begin{array}{l}\mathrm{r}_{\text {hitung }} \\
\mathrm{r}_{\text {tabel }}\end{array}$ & $>$ & Valid \\
\hline Pernyataan_3 & 0,675 & 0,361 & $\begin{array}{l}r_{\text {hitung }} \\
r_{\text {tabel }}\end{array}$ & $>$ & Valid \\
\hline Pernyataan_4 & 0,605 & 0,361 & $\begin{array}{l}\mathrm{r}_{\text {hitung }} \\
\mathrm{r}_{\text {tabel }}\end{array}$ & $>$ & Valid \\
\hline Pernyataan_5 & 0,813 & 0,361 & $\begin{array}{l}r_{\text {hitung }} \\
r_{\text {tabel }}\end{array}$ & $>$ & Valid \\
\hline Pernyataan_6 & 0,709 & 0,361 & $\begin{array}{l}\mathrm{r}_{\text {hitung }} \\
\mathrm{r}_{\text {tabel }}\end{array}$ & $>$ & Valid \\
\hline Pernyataan_7 & 0,699 & 0,361 & $\begin{array}{l}r_{\text {hitung }} \\
r_{\text {tabel }}\end{array}$ & $>$ & Valid \\
\hline Pernyataan_8 & 0,627 & 0,361 & $\begin{array}{l}\mathrm{r}_{\text {hitung }} \\
\mathrm{r}_{\text {tabel }}\end{array}$ & $>$ & Valid \\
\hline Pernyataan_9 & 0,787 & 0,361 & $\begin{array}{l}\mathrm{r}_{\text {hitung }} \\
\mathrm{r}_{\text {tabel }}\end{array}$ & $>$ & Valid \\
\hline Pernyataan_10 & 0,787 & 0,361 & $\begin{array}{l}\mathrm{r}_{\text {hitung }} \\
\mathrm{r}_{\text {tabel }}\end{array}$ & $>$ & Valid \\
\hline
\end{tabular}

Uji reliabilitas instrumen menggunakan rumus Alpha Cronbach ( $\left.\mathrm{r}_{11}\right)$. Dari hasil pengolahan data diperoleh nilai koefisien $\mathrm{r}_{11}$ seperti terlihat pada Tabel 3 .

Tabel 3. Hasil Uji Reliabilitas Instrumen

\begin{tabular}{ccc}
\hline Variabel & Koefisien Alfa & Simpulan \\
\hline Kerjasama $\left(\mathrm{X}_{1}\right)$ & 0,927 & Reliabel \\
$\begin{array}{c}\text { Kinerja pegawai } \\
(\mathrm{Y})\end{array}$ & 0,926 & Reliabel \\
\hline
\end{tabular}

Berdasarkan Tabel 3. terlihat bahwa keseluruhan nilai $\mathrm{r}_{11}$ lebih besar dari 0,6 , dengan demikian dapat dikatakan bahwa kuisioner dalam penelitian ini reliabel, yang mengandung arti bahwa kuisioner tersebut akan selalu menghasilkan data yang sama dalam waktu yang berbeda, walaupun responden juga berbeda. Atau dengan kata lain, kuisioner tersebut dapat diandalkan dan dipercaya untuk mengumpulkan data.

\section{Analisis Kualitatif}

Berdasarkan interval kelas, maka distribusi frekuensi variabel kerjasama dapat dilihat pada Tabel 4.
Tabel 4. Distribusi Jawaban Responden tentang Kerjasama

\begin{tabular}{|c|c|c|c|c|}
\hline No & Kategori & $\begin{array}{c}\text { Skor } \\
\text { Interval } \\
\text { Kelas } \\
\end{array}$ & Frekuensi & $\begin{array}{c}\text { Persentase } \\
(\%)\end{array}$ \\
\hline 1. & $\begin{array}{l}\text { Sangat } \\
\text { setuju }\end{array}$ & $42-50$ & 11 & 21,15 \\
\hline 2. & Setuju & $34-41$ & 23 & 44,23 \\
\hline 3. & $\begin{array}{l}\text { Kurang } \\
\text { setuju }\end{array}$ & $26-33$ & 17 & 32,69 \\
\hline 4. & $\begin{array}{l}\text { Tidak } \\
\text { setuju }\end{array}$ & $18-25$ & 1 & 1,92 \\
\hline 5. & $\begin{array}{l}\text { Sangat } \\
\text { tidak } \\
\text { setuju }\end{array}$ & $10-17$ & 0 & 0,00 \\
\hline \multicolumn{3}{|c|}{ Jumlah } & 52 & 100,0 \\
\hline
\end{tabular}

Berdasarkan Tabel 4. diketahui sebanyak 11 responden atau $21,15 \%$ menyatakan kerjasama dalam kategori sangat setuju, 23 responden atau $44,23 \%$ menyatakan kerjasama dalam kategori setuju, 17 responden atau 32,69\% menyatakan kerjasama dalam kategori kurang setuju, 1 responden atau 1,92\% menyatakan kerjasama dalam kategori tidak setuju dan tidak ada responden yang menyatakan kerjasama dalam kategori sangat tidak setuju. Dapat disimpulkan bahwa kerjasama pegawai pada Biro Humas dan Protokol Sekretariat Daerah Provinsi Lampung termasuk dalam kategori "setuju".

Berdasarkan interval kelas, maka distribusi frekuensi variabel kinerja pegawai dapat dilihat pada Tabel 5 .

Tabel 5. Distribusi Jawaban Responden Tentang Kinerja Pegawai

\begin{tabular}{|c|c|c|c|c|}
\hline No & Kategori & $\begin{array}{c}\text { Skor } \\
\text { Interval } \\
\text { Kelas }\end{array}$ & Frekuensi & $\begin{array}{c}\text { Persentase } \\
(\%)\end{array}$ \\
\hline 1. & $\begin{array}{l}\text { Sangat } \\
\text { setuju }\end{array}$ & $42-50$ & 12 & 23,07 \\
\hline 2. & Setuju & $34-41$ & 25 & 48,08 \\
\hline 3. & $\begin{array}{l}\text { Kurang } \\
\text { setuju }\end{array}$ & $26-33$ & 15 & 28,85 \\
\hline 4. & $\begin{array}{l}\text { Tidak } \\
\text { setuju }\end{array}$ & $18-25$ & 0 & 0,00 \\
\hline 5. & $\begin{array}{l}\text { Sangat } \\
\text { tidak } \\
\text { setuju }\end{array}$ & $10-17$ & 0 & 0,00 \\
\hline \multicolumn{3}{|c|}{ Jumlah } & 52 & 100,0 \\
\hline
\end{tabular}


Berdasarkan Tabel 5, diperoleh jawaban sebanyak 12 responden atau 23,07\% menyatakan kinerja dalam kategori sangat setuju, 25 responden atau 48,08\% menyatakan kinerja dalam kategori setuju, 15 responden atau $28,85 \%$ menyatakan kinerja dalam kategori kurang setuju, dan tidak ada responden yang menyatakan kinerja pegawai dalam kategori tidak setuju maupun sangat tidak setuju. Hal ini mengandung arti bahwa kinerja pegawai pada Biro Humas dan Protokol Sekretariat Daerah Provinsi Lampung secara dominan termasuk dalam kategori setuju, kondisi ini perlu dipertahankan.

\section{Analisis Kuantitatif}

Berdasarkan hasil uji tersebut maka didapatkan persamaan model regresi yang sebagai berikut :

$$
\begin{aligned}
\mathrm{Y} & =16,716+0,563 \mathrm{X}+\mathrm{e} \\
\mathrm{t}_{\text {hitung }} & =(5,861) \mathrm{t}_{\text {hitung }}>\mathrm{t}_{\text {tabel }}(2,021) \\
\mathrm{KP} & =\mathrm{r}^{2} \times 100 \% \\
& =(0,638)^{2} \times 100 \% \\
& =(0,407) \times 100 \% \\
& =40,7 \%
\end{aligned}
$$

Berdasarkan hasil analisis data secara kualitatif dan kuantitatif, dapat disimpulkan bahwa kerjasama berpengaruh terhadap kinerja pegawai Biro Humas dan Protokol Sekretariat Daerah Provinsi Lampung. Hal ini mengandung arti bahwa semakin tinggi kerjasama maka akan mampu meningkatkan kinerja pegawai itu sendiri.

Pernyataan tentang kerjasama rata-rata dijawab setuju (skor 72,35) oleh responden yaitu Biro Humas dan Protokol Sekretariat Daerah Provinsi Lampung. Jawaban pegawai ini dapat disimpulkan kerjasama yang tercipta di antara pegawai sudah dalam kondisi baik walaupun terkadang rasa kekompakan yang tercipta di antara pegawai sering diabaikan sehingga terdapat ketidakharmonisan. Hal ini berbanding lurus dengan pernyataan tentang kinerja pegawai dengan rata-rata dijawab setuju (skor 74,15) oleh responden yaitu Biro Humas dan Protokol Sekretariat Daerah Provinsi Lampung. Jawaban pegawai ini dapat disimpulkan jika kinerja pegawai pada Biro Humas dan Protokol Selretariat Daerah Provinsi Lampung dalam kondisi yang baik, sehingga perlu untuk dipertahankan dan ditingkatkan pada masa yang akan datang.

Kerjasama berpengaruh signifikan terhadap kinerja pegawai yang ditunjukkan dengan nilai thitung 5,861 lebih besar dari nilai ttabel $(2,021)$ atau dengan kata lain thitung > ttabel, sedangkan hasil significant yang diperoleh sebesar 0,000, lebih kecil dari yang ditentukan yaitu 0,05 sehingga dapat dikatakan signifikan. Dengan demikian, Ho ditolak dan Ha diterima, atau dengan kata lain terdapat pengaruh kerjasama terhadap kinerja pegawai pada Biro Humas dan Protokol Sekretariat Daerah Provinsi Lampung.

Kerjasama yang baik pada dasarnya akan mampu mengoptimalkan kinerja pegawai dalam suatu organisasi. Hal ini sesuai dengan pendapat Abdulsyani (2004), bahwa kerjasama merupakan salah satu bentuk interaksi sosial, dimana di dalamnya terdapat aktivitas tertentu untuk mencapai tujuan bersama dengan saling membantu dan saling memahami aktivitas masingmasing. Atau dengan kata lain, kerjasama berarti bekerja secara bersama-sama untuk mencapai tujuan bersama. Ia adalah satu proses sosial yang paling dasar. Biasanya, kerjasama melibatkan pembagian tugas, dimana setiap orang mengerjakan setiap pekerjaan yang merupakan tanggung jawab demi tercapainya tujuan bersama.

Hasil penelitian ini sejalan dengan penelitian Poernomo (2006) bahwa kreativitas dan kerjasama tim berpengaruh terhadap kinerja manajer terbukti kebenarannya, hal ini dapat dilihat dari nilai R2 yang diperoleh sebesar 0,671 yang berarti bahwa kreativitas dan kerjasama tim 
secara simultan mampu menjelaskan variasi dari kinerja manajer sebesar $67,1 \%$ dan sisanya sebesar $32,9 \%$ dijelaskan oleh variabel lain yang tidak dibahas pada penelitian ini. Dan bisa juga dilihat dari nilai korelasi (R)-nya yang sebesar 0,819 menunjukkan korelasi yang sangat kuat antara kreativitas dan kerjasama tim dengan kinerja manajer yaitu sebesar $81,9 \%$.

Berdasarkan uraian di atas, dapat disimpulkan bahwa semakin baik kerjasama yang dimiliki oleh pegawai dalam melaksanakan pekerjaan, maka akan semakin baik pula kinerja pegawai, begitu pula sebaliknya, jika kerjasama yang dimiliki oleh pegawai dalam melaksanakan pekerjaan tidak baik, maka kinerja pegawai akan menurun.

\section{KESIMPULAN DAN SARAN}

\section{Kesimpulan}

Berdasarkan hasil pembahasan dan analisis setiap variabel penelitian maka dapat dirumuskan kesimpulan bahwa terdapat pengaruh kerjasama terhadap kinerja pegawai pada Biro Humas dan Protokol Sekretariat Daerah Provinsi Lampung. Hal ini dapat dilihat dari nilai $t_{\text {hitung }}(\mathrm{X}=5,861$, sig $=0,000)$ yang diperoleh lebih besar dari nilai $t_{\text {tabel }}(2,021)$. Nilai $R^{2}$ yang diperoleh sebesar 0,407, artinya varian kerjasama mampu menjelaskan varian kinerja pegawai sebesar $40,7 \%$, sisanya dijelaskan oleh variabel lain di luar model.

\section{Saran}

Adapun saran yang diajukan peneliti adalah sebagai berikut:

1. Hasil penelusuran untuk variabel kerjasama, diperoleh skor terendah tentang kekompakan antara pegawai membuat kerjasama semakin solid. Untuk masalah ini, hendaknya pegawai
Biro Humas dan Protokol Sekretariat Daerah Provinsi Lampung meningkatkan kekompakkan dalam lingkup kerjasama di antara pegawai, sehingga mampu tercipta kerjasama yang harmonis baik di dalam maupun di luar organisasi.

2. Hasil penelusuran untuk variabel kinerja pegawai, diperoleh skor terendah tentang saya mencapai target kuantitas kerja yang telah direncanakan. Untuk masalah ini, Kepala Biro dan Humas melakukan pengawasan secara intensif baik melalui inspeksi mendadak (sidak) dan pemberian sanksi disiplin. Di sisi lain, pegawai Biro Humas dan Protokol Sekretariat Daerah Provinsi Lampung hendaknya menerapkan disiplin kerja yang tinggi, seperti masuk tepat waktu, tidak meninggalkan pekerjaan ketika jam kerja sampai pulang tepat pada waktunya, sehingga pekerjaan tidak terbengkalai.

\section{DAFTAR PUSTAKA}

Abdulsyani. 2004. Manajemen Sumber Daya Manusia. Jakarta: Penerbit Bumi Aksara.

Ahmadi, Abu. 2004. Sosiologi Pendidikan. Jakarta: PT Rineka Cipta.

Arikunto, Suharsimi. 2002. Prosedur Penelitian. Edisi Kelima. Jakarta: Penerbit Bineka Cipta.

Barnad. 2001. Konsep Manajemen Sumber Daya Manusia Edisi Pertama. Jakarta: Pustaka Abadi.

Chung, Robert Mc \& Meggison, Sammi. 2008. Organisasi: Struktur, Teori, dan Proses. Alih Bahasa. Jakarta: Ghalia Indonesia.

Foster, Bill \& Seeker, Karen R. 2001. Pembinaan untuk Meningkatkan 
Kinerja Karyawan. Penerjemah Sugiyono. 2010. Metode Penelitian Ramlan. Jakarta: PPM.

Kuantitatif dan Kualitatif dan $R \& D$. Bandung : CV.Alpha Beta.

Ghozali, Imam. 2005. Aplikasi Analisis Multivariate Dengan Program SPSS. Semarang: Badan Penerbit Undip.

Sulistyani, AT. 2003. Manajemen Personalia. Yogyakarta: Graha Ilmu.

Mangkunegara, Anwar P. 2004. West, Richard. 2002. Pengantar Teori Manajemen Sumber Daya Manusia Perusahaan. Bandung: PT.Remaja Komunikasi: Analisis dan Aplikasi. Jakarta: Salemba Empat.

Rosdakarya.

Mangkuprawira, Sjafri. 2009. Manajemen Mutu Sumber Daya Manusia. Bogor: Ghalia Indonesia.

Mathis, Robert \& Jackson, John. 2002. Manajemen Sumber Daya Manusia. Jilid 2. Jakarta: Salemba Empat.

Narwoko, Dwi. 2004. Sosiologi Teks Pengantar dan Terapan. Jakarta: Kencana Media Group.

Nawawi, Hadari. 2005. Perencanaan SDM: untuk Organisasi Profit. Yogyakarta: Gajah Mada University.

Pareek. 2003. Leadership Kompeten. Bandung: Bina Pustaka.

Sentono, Prawiro. 2003. Mengembangkan Kreativitas dalam Organisasi (Edisi 1). Yogjakarta: Kanisius.

Siagian, Sondang P. 2006. Manajemen Sumber Daya Manusia. Cetakan Ketiga Belas. Jakarta: PT. Bumi Aksara.

Sopiah. 2008. Manajemen Sumber Daya Manusia. Edisi Pertama. Yogyakarta: Penerbit Graha Ilmu. 